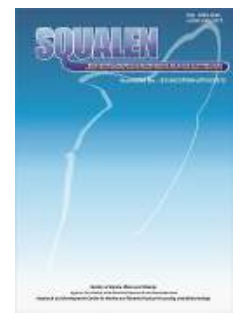

\title{
INFLUENCE OF ANTHROPOGENIC PRESSURES ON THE BIOACTIVITY POTENTIAL OF SPONGES AND SOFT CORALS IN THE CORAL REEF ENVIRONMENT
}

\author{
Hedi Indra Januar ${ }^{1,2,3^{*}}$, Ekowati Chasanah ${ }^{1,3}$, Dianne M. Tapiolas ${ }^{3}$, Cherie A. Motti ${ }^{3}$, \\ Catherine H. Liptrot ${ }^{3}$, and Anthony D. Wright ${ }^{3,4}$ \\ ${ }^{1}$ Research and Development Center for Marine and Fisheries Product Processing and Biotehnology, \\ Jalan KS. Tubun Petamburan VI, Slipi, Central Jakarta 10260, Indonesia; \\ ${ }^{2}$ Department of Marine Science, Faculty of Fisheries and Marine Science, Bogor Agricultural University, Indonesia, \\ Jalan Raya Dramaga Kampus IPB, Bogor, Indonesia 16680; \\ ${ }^{3}$ Australian Institute of Marine Science, PMB No. 3 Townsville MC, Townsville, Australia 4810 \\ ${ }^{4}$ Right Consulting, 15 Amauulu Road, Hilo USA 96720. \\ Article history: \\ Received: 18 May 2015; Revised: 20 June; Accepted: 25 June 2015
}

\begin{abstract}
The wealth of marine sponges and soft corals in Indonesian waters represents a rich source of natural products. However, anthropogenic pressures potentially decrease diversity in coral reefs. Presented here are trends for tropical sponge and soft coral biodiversity and their bioactivity potential under the influence of increasing anthropogenic pressures. Samples were collected along transects (near, mid, and far) at Karimunjawa and Seribu Islands Marine National Parks and environmental parameters (salinity, pH, dissolved oxygen (DO), phosphate, nitrate, and ammonia), sponge and soft coral biodiversity, and the bioactivity potential of those organisms (50\% Growth Inhibition $\left(\mathrm{GI}_{50}\right.$ ) of cancer cell lines H460-Lung, MCF7-Breast, and SF268-CNS) are compared. The environmental conditions and biodiversity were found to be significantly different between groups of sampling sites $(P<0.05)$. Canonical Discriminant Analysis $(C D A)$ revealed DO was the discriminant factor driving the separation between groups $(90.1 \%)$. Diversity tended to be higher in the Far group with strong and significant relation to $D O(R$ $=0.611, \mathrm{P}<0.05)$ and ammonia $(\mathrm{R}=-0.812, \mathrm{P}<0.05)$. The CDA also showed that an increase in bioactivity (low \% $\mathrm{GI}_{50}$ ) of sponge and soft coral extracts was related to a canonical function $(57.21 \%)$ consisting of high $\mathrm{DO}$, high $\mathrm{pH}$, and low nutrients. These findings indicate the production of bioactive compounds is related to diversity and complexity of coral reef systems. Therefore, strategies for marine protection by mitigating the impacts of anthropogenic pressures needs to be optimized in order to conserve the overall environment and sustain its natural bioactivity potential indefinitely.
\end{abstract}

Keywords: bioactivity potential, sponges, soft corals, Seribu Islands, Karimunjawa

\section{Introduction}

The search for biologically active natural products from coral reef organisms has been a topic of considerable interest for at least three decades. The occurrence of bioactive compounds in benthic organisms such as sponges and soft corals is directly related their ecological challenges, e.g., defensive or offensive strategies in living space maintenance (Haber et al. 2011 ; Pawlink, 2011; De Caralt et al. 2013). It can be inferred from an ecological point of view that the diversity and complexity of coral reef communities are key to the production of bioactive compounds by benthic organisms. However, significant anthropogenic pressures arise in regions adjacent to coral reefs that cause considerable damage to both their structure and integrity. Examples include, coral mining, destructive fishing activities, domestic industrial aquatic pollution, all of which are direct threats to the diversity of benthic coral reef communities (Crabbe et al., 2004; Caras \& Pasternak, 2009; Haapkyla et al. 2009; Aeby et al., 2011). Furthermore, these anthropogenic activities have all been reported as causes of tropical coral reef degradation. An increase

${ }^{*}$ Corresponding author.

E-mail: idjanuar@kkp.go.id 
of dissolved inorganic nitrogen was recorded from 1997-2004 in the Seribu Islands Marine National Park, revealing that significant pressures are being placed on that environment by human activity (Sachoemar, 2008).

The production of bioactive compounds is influenced by ecological factors. Research in this area has so far been restricted to particular invertebrate species, and there are only a few reports concerning the effects of anthropogenic pressures on the overall bioactivity potential of marine benthic invertebrates, especially in Indonesian tropical coral communities. Previous research has shown that production is negatively related to water quality and positively related to biodiversity of predators and benthic competition (Fleury et al., 2004; Hoover et al., 2008; Januar et al., 2011; 2012; He et al., 2014). Thus, the research reported here looked to see if there were any bioactive compound production shifts as reefs degrade and change, and investigated directly whether there is any clear correlation between prevailing environmental conditions and biodiversity, and the bioactivity potential of sponges and soft corals. Two marine parks were selected for the study, namely the Karimunjawa and Seribu Islands Marine National Parks, as representatives of coral reef areas that are currently exposed to anthropogenic pressures (Edinger et al. (1998) and Sachoemar (2008)).

\section{Material and Methods}

\subsection{Study Sites and Water Quality Analysis}

The study was conducted at Karimunjawa and Seribu Islands Marine National Parks, northern part of Java Island, Indonesia (Figure 1a \& 1b). Three representative sites (Near, Mid, and Far) were selected at each location along a distance gradient from the main inhabited island (Karimunjawa and Pramuka Island) to investigate possible relationships concerning biodiversity and bioactivity potential under the influence of anthropogenic pressures.

The sites at $3 \mathrm{~km}$ (Menjangan Kecil Island, $\mathrm{S}^{\circ}$ $\left.53^{\prime} 24.4^{\prime \prime} \mathrm{E} 110^{\circ} 24^{\prime} 08.3^{\prime \prime}\right), 11 \mathrm{~km}$ (Burung Island, S5 ${ }^{\circ}$ $\left.53^{\prime} 22.1^{\prime \prime} \mathrm{E} 110^{\circ} 20^{\prime} 26.0^{\prime \prime}\right)$, and $16 \mathrm{~km}$ (Bengkoang Island, S5 ${ }^{\circ} 44^{\prime} 30.2^{\prime \prime}$ E110 $24^{\prime}$ 07.2"), from Karimunjawa Island Harbor represented Near, Mid, and Far environmental conditions in Karimunjawa Marine National Park (Figure 1c). Likewise, the sites at 0.5 km (Gosong Panggang, S5 $\left.44^{\prime} 34.5^{\prime \prime} \mathrm{E} 106^{\circ} 36^{\prime} 37.8^{\prime \prime}\right)$, 3 km (Ayer Island, S5 ${ }^{\circ} 45^{\prime} 37.8^{\prime \prime}$ E106 $\left.{ }^{\circ} 35^{\prime} 26.6^{\prime \prime}\right)$, and $9 \mathrm{~km}$ (Kotok Island, $\left.5^{\circ} 42^{\prime} 23.0^{\prime \prime} \mathrm{E} 106^{\circ} 32^{\prime} 24.6^{\prime \prime}\right)$ from Pramuka Island Harbor represented Near, Mid, and Far environmental conditions in Seribu Islands Marine National Park (Figure 1d). Location of the sampling sites was recorded by Garmin eTrex 10 GPS and plotted to OpenSeaMap chart with Garmin Basecamp 4.4.6. Water samples $(n=3)$ were taken from each of the six sites. Analysis of phosphate $\left(\mathrm{PO}_{4}{ }^{3-}\right)$, nitrate $\left(\mathrm{NO}^{3-}\right)$, ammonia $\left(\mathrm{NH}_{3}\right), \mathrm{DO}$, and $\mathrm{pH}$ were conducted immediately on board, above the sampling site, using a portable colorimeter Hach DR890 and a rugged probe $\mathrm{DO}$ and $\mathrm{pH}$-meter.

\subsection{Sample Collection, Extraction, Taxonomic Identification, and Bioassay}

Fresh soft corals and sponges $(n=46)$ were harvested by SCUBA diving with the intent of collecting as many different genera from each site. Samples were immediately immersed in methanol $\left(\mathrm{CH}_{3} \mathrm{OH}\right)$ until required. On return to the laboratory samples were divided into two portions. The first portion $(5 \mathrm{~g})$ was macerated twice (each for 24 hours) with ice cold $\mathrm{CH}_{3} \mathrm{OH}$. Resultant extracts were filtered, evaporated
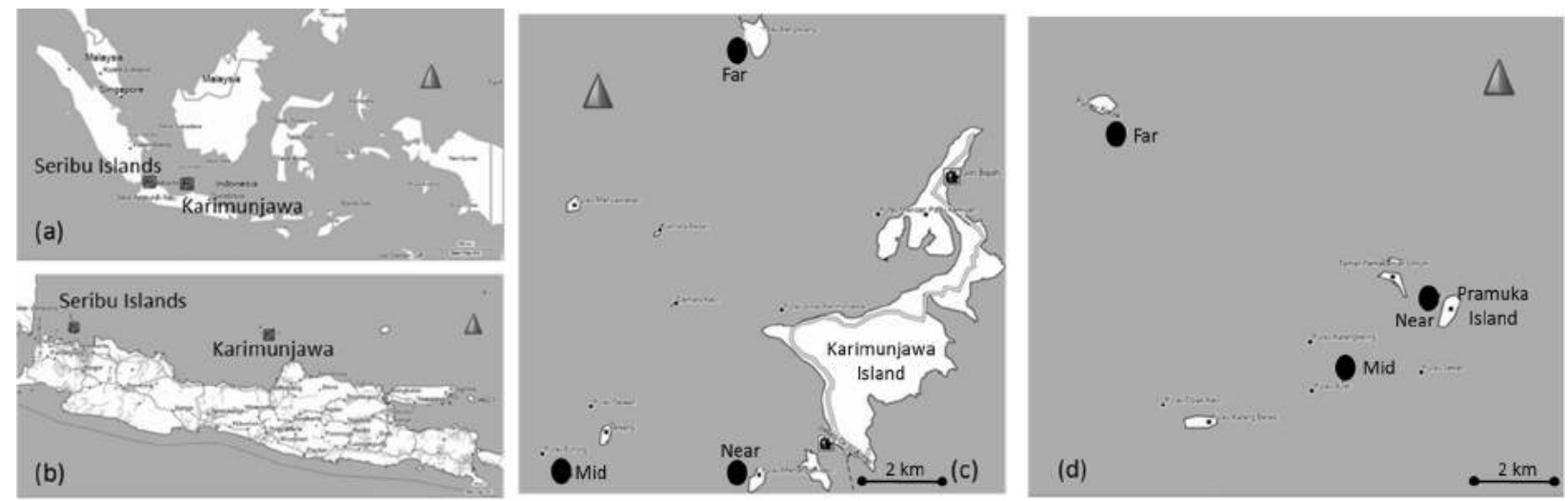

Figure 1. Sampling sites in (a) Indonesia, (b) northern side of mainland Java Island, (c) coral reef sites in Karimunjawa Marine National Park, Near $=3 \mathrm{~km}$ (Menjangan Kecil Island), Mid $=11 \mathrm{~km}$ (Burung Island), and Far $=16 \mathrm{~km}$ (Bengkoang Island) from the main Karimunjawa Island Harbor and (d) coral reef sites in Seribu Islands Marine National ParkNear $=0.5 \mathrm{~km}$ (Gosong Panggang), Mid $=3$ $\mathrm{km}$ (Ayer Island), and Far=9 km (Kotok Island) from Pramuka Island Harbor. 


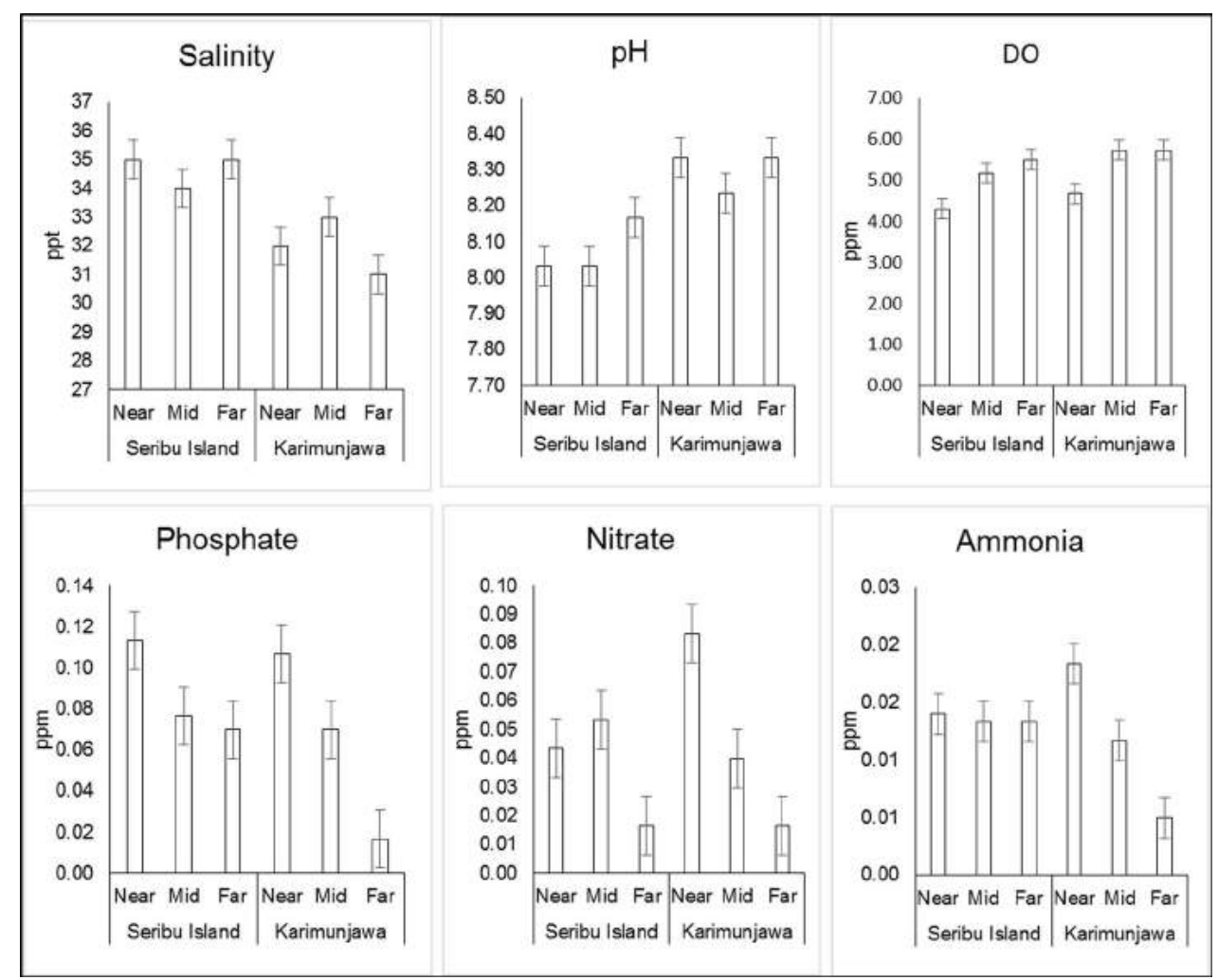

Figure 2. Averages of salinity, $\mathrm{pH}, \mathrm{DO}$, phosphate, nitrate, and ammonia concentration at sampling sites (Mean $\pm S D$, with $n=3$ ), with Near, Mid, and Far representing the distance of each site from the main inhabited island in the marine parks (Karimunjawa and Seribu Islands; Figure 1).

to dryness by rotary evaporation and lyophilised. The second portion was stored for taxonomic identification. Taxonomic identification of sponges was conducted at the Australian Institute of Marine Science (AIMS), based on Hooper (2003). Meanwhile, soft coral identification was undertaken by K. Fabricius, AIMS, based on Fabricius (2008).

All $\mathrm{CH}_{3} \mathrm{OH}$ extracts were tested for their cytotoxic activity towards three human tumor cell lines; H460 (lung), MCF-7 (breast) and SF268 (CNS). Extract doses ranging from 3.1 to $250 \mu \mathrm{g} / \mathrm{ml}$ were tested so as to obtain $I G_{50}$ values for each. The cytotoxicity screening was conducted using the sulforhodamine B (SRB) assay based on Skehan et al. (1990).

\subsection{Data Analysis}

Data processing and statistical analyses were performed according to Huang et al. (2011). Differences in seawater variables and bioactivity levels at each site was analysed by Kruskall-Wallis analysis. Quantification of the relationship between seawater variables and diversity of samples were analysed by bivariate Spearman analysis. Canonical Discriminant Analysis (CDA) was employed to define the pattern of environmental conditions at Near, Mid, and Far sites in both marine parks. The bioactivity was graded for the multivariate analysis, where $\mathrm{IG}_{50}<20 \mu \mathrm{g} / \mathrm{ml}$ was categorized as High, $20-100 \mu \mathrm{g} / \mathrm{ml}$ as Moderate, and $100-250 \mu \mathrm{g} / \mathrm{ml}$ as Low. An $\mathrm{IG}_{50}>250 \mu \mathrm{g} / \mathrm{ml}$ was classified as Inactive. To define the pattern of environmental conditions, a CDA was applied to sponges and soft corals that showed a specific level of cytotoxic activity (High, Moderate, Low, and Inactive). Analysis of Similarities (ANOSIM) and Similarity Percentage (SIMPER) were applied to determine the differences between environmental parameters at each site (Near, Mid, and Far), and between each bioactivity group (High, Moderate, Low, and Inactive), as well as the factors that contributed to these differences. Prior to multivariate analyses, data were log transformed and normalized. All statistical analyses were performed with Past Statistical Software v3.08 (Hammer et al. 2001).

\section{Results and Discussion}

\subsection{Environmental Parameters}

Seawater parameters measured at sampling sites (depth 5-9 m) in both marine parks are shown in Figure 2. 


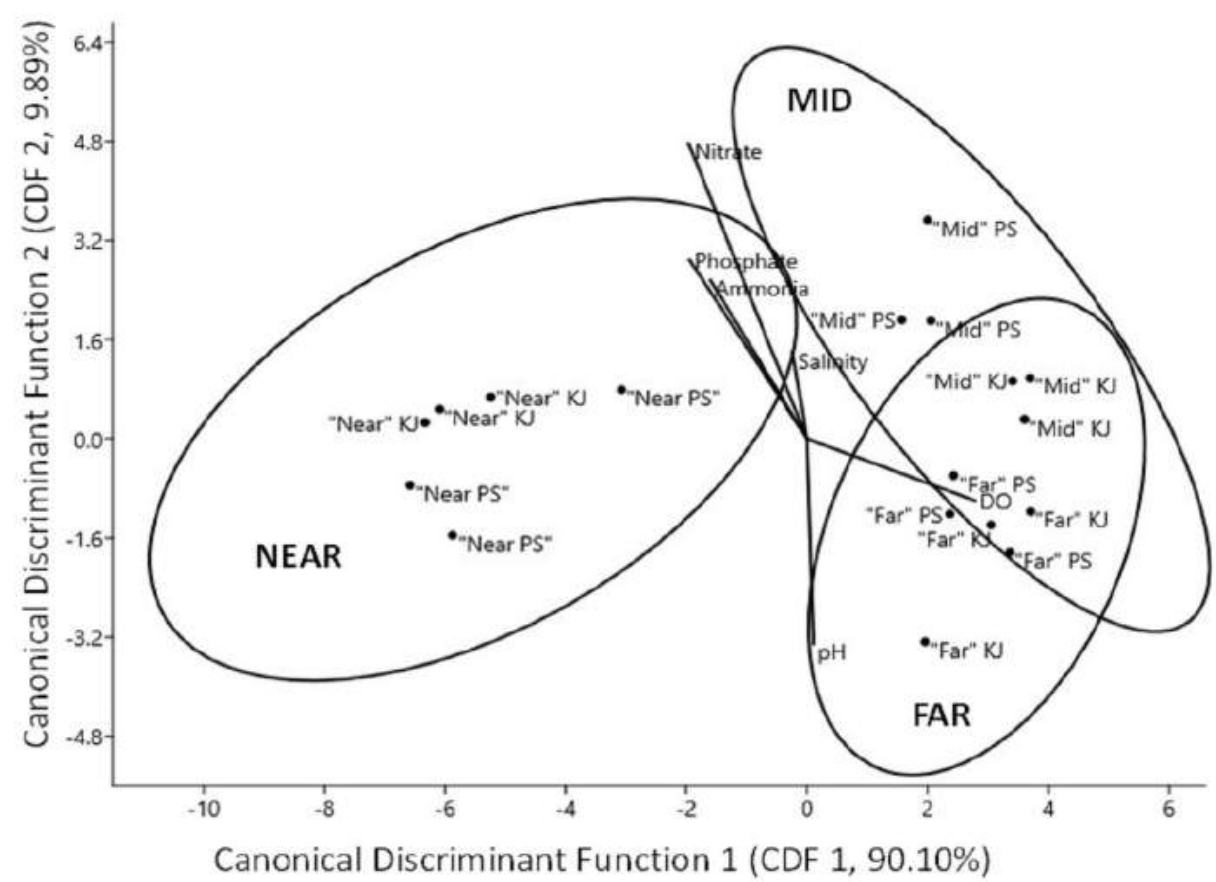

Figure 3. CDA (with 95\% eclipses) for environmental parameters at sampling sites, with Near, Mid, and Far representing the distance of the site from the main inhabited island in Karimunjawa (Karimunjawa Isalnd, KJ) and Seribu Islands (Pramuka Island, PS) marine parks (see Figure 1).

A gradual increase of $\mathrm{pH}$ in Karimunjawa Marine National Park and of DO in both marine parks was noted in going from Near to Far sites. Conversely, nutrient levels $\left(\mathrm{PO}_{4}^{3-}, \mathrm{NO}^{3-}\right.$ and $\left.\mathrm{NH}_{3}\right)$ either decreased or remained constant along the distance gradient. A statistically significant pattern was not observed for salinity in either marine park. Statistical unconstrained multivariate Canonical Discriminant Analysis (CDA) was used to define the most discriminating environmental parameters at sampling sites in both marine parks (Figure 3).

The CDA found DO and nutrient levels explained the variance of environmental parameters at different sites in both marine parks. The level of DO mainly contributed to CDF 1 and explained $90.1 \%$ of variance, while nutrient levels $\left(\mathrm{PO}_{4}{ }^{3-}, \mathrm{NO}^{3-}\right.$ and $\left.\mathrm{NH}_{3}\right)$ contributed to CDF 2 and explained $9.89 \%$ of variance between groups of sites. Multivariate One-Way ANOSIM confirmed the Near sites were significantly different from Mid and Far sites $(P<0.05)$ and that Mid and Far were not significantly different from each other based on significant overlap of their $95 \%$ confidence limit eclipses. The difference between groups of sites was explained by SIMPER that showed DO, $\mathrm{PO}_{4}{ }^{3-}$ and $\mathrm{NH}_{3}(60.55 \%)$ were the main contributing factors.

Nutrient rich effluents entering coral reef environments usually come from domestic runoff or chemical fertilizers, indicating human activities are responsible for negative pressures put on reefs
(Shuiwang et al., 2000). Higher DO values may indicate differences in localized hydrodynamics, such as stronger currents, resulting in greater exchange of water and/or negligible organic contamination in the environment. However, the results of this analysis confirmed that the six reef locations examined were impacted by anthropogenic pressures and that these pressures generally decreased with distance from the inhabited islands in both marine parks.

\subsection{Diversity of Sponges and Soft Corals}

Taxonomic identification of the 46 sponge and soft coral samples revealed that examples from 20 different genera had been collected from Karimunjawa and Seribu Islands Marine National Parks (Table 1). Fourteen genera were sponges (phylum Porifera) and six were soft corals belonging to the phylum Cnidaria, class Anthozoa, subclass Octocorallia, order Alcyonacea. A Kruskal-Wallis statistical analysis found the diversity between locations (Seribu Island and Karimunjawa) was not significantly different for sponges but was significantly different for soft corals $(P<0.05)$. The average ratio of sponge to soft coral diversity in Seribu Islands Marine National Park was roughly 1:1 while in Karimunjawa Marine National Park it was found to be 3:1 (Figure 4a). Biogeographically favourable growth parameters, recruitment dispersion, settlement substrata, predatory pressures and/or other specific conditions not considered in this research 
Table 1. Taxonomic assignment of samples from reefs in the Karimunjawa and Seribu Islands Marine National Parks, with Near, Mid, and Far representing the distance of the site from the main inhabited island (Karimunjawa and Pramuka Islands; Figure 1).

\begin{tabular}{|c|c|c|c|c|c|c|c|c|}
\hline \multirow{2}{*}{ No } & \multirow{2}{*}{\multicolumn{2}{|c|}{ Taxonomic Assignment }} & \multicolumn{3}{|c|}{ Karimunjawa } & \multicolumn{3}{|c|}{ Seribu Islands } \\
\hline & & & NEAR & MID & FAR & NEAR & MID & FAR \\
\hline 1 & \multirow{14}{*}{ Sponge } & Aaptos sp. & $\sqrt{ }$ & $\sqrt{ }$ & $\sqrt{ }$ & & & \\
\hline 2 & & Acanthella sp. & & & $\sqrt{ }$ & & & \\
\hline 3 & & Axinella sp. & $\sqrt{ }$ & & $\sqrt{ }$ & & & \\
\hline 4 & & Callyspongia sp. & & $\sqrt{ }$ & & $\sqrt{ }$ & $\sqrt{ }$ & \\
\hline 5 & & Clathria sp. & $\sqrt{ }$ & $\sqrt{ }$ & $\sqrt{ }$ & & & \\
\hline 6 & & Cribochalina sp. & & & $\sqrt{ }$ & & & \\
\hline 7 & & Dactylia sp. & & $\sqrt{ }$ & & & & \\
\hline 8 & & Dictyonellida sp. & & & & & & $\sqrt{ }$ \\
\hline 9 & & Geodiidae sp. & & & & & $\sqrt{ }$ & \\
\hline 10 & & Neofibularia sp. & & & $\sqrt{ }$ & & & $\sqrt{ }$ \\
\hline 11 & & Niphates sp. & & $\sqrt{ }$ & $\sqrt{ }$ & $\sqrt{ }$ & & \\
\hline 12 & & Rhabdastrella sp. & & & $\sqrt{ }$ & & $\sqrt{ }$ & $\sqrt{ }$ \\
\hline 13 & & Xestospongia sp. & & & & & $\sqrt{ }$ & \\
\hline 14 & & unidentified & & & $\sqrt{ }$ & & $\sqrt{ }$ & $\sqrt{ }$ \\
\hline 15 & \multirow{6}{*}{ Soft Coral } & Dendronephthya sp. & $\sqrt{ }$ & & & $\sqrt{ }$ & $\sqrt{ }$ & $\sqrt{ }$ \\
\hline 16 & & Nephthea sp. & & & & & $\sqrt{ }$ & $\sqrt{ }$ \\
\hline 17 & & Sarcophyton sp. & $\sqrt{ }$ & & $\sqrt{ }$ & & $\sqrt{ }$ & $\sqrt{ }$ \\
\hline 18 & & Sinularia sp. & $\sqrt{ }$ & & $\sqrt{ }$ & $\sqrt{ }$ & & \\
\hline 19 & & Gorgoniacea sp. & & & & & $\sqrt{ }$ & $\sqrt{ }$ \\
\hline 20 & & Lobophytum sp. & & & & & $\sqrt{ }$ & $\sqrt{ }$ \\
\hline
\end{tabular}

might be factors behind the tendency towards higher soft coral diversity at the Seribu Islands Marine National Park sites and similarly for the tendency towards greater sponge diversity in Karimunjawa Marine National Park. Furthermore, the difference in sponge and soft coral diversity between sites (Near, Mid, and Far) was found to be significantly different $(P<0.05)$ in both locations. Overall, the study found diversity decreased as distance between the mainland and the sites decreased (Figure $4 \mathrm{~b}$ ). This likely serves as an indication of biodiversity loss through anthropogenic stressors emanating from the inhabited islands within both marine parks.

According to a Spearman Rank analysis the relationship between diversity and environmental variables was a bivariate correlation. Higher diversity
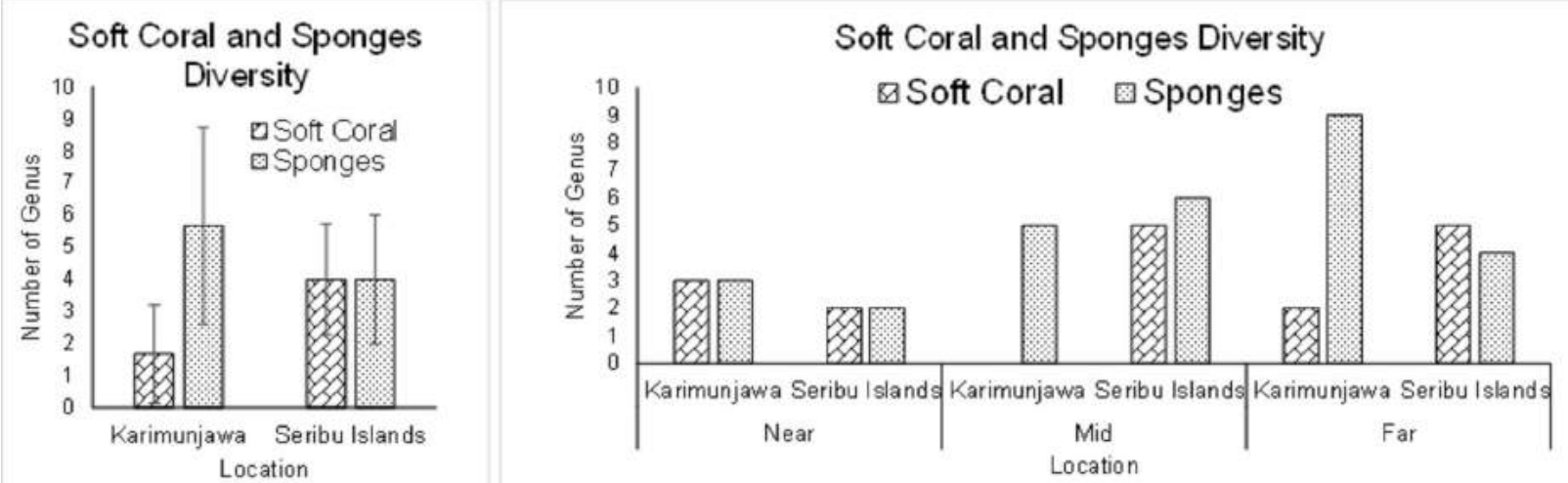

Figure 4. Average of soft coral and sponge diversity found (a) in the Karimunjawa and Seribu Islands Marine National Parks, and (b) at each site, with Near, Mid, and Far representing the distance of the site from the main inhabited island in the marine parks (Karimunjawa and Pramuka Islands; Figure 1). 
was found in the Far group, with strong and significant correlation to $\mathrm{DO}(\mathrm{R}=0.611, \mathrm{P}<0.05)$ and $\mathrm{NH}_{3}(\mathrm{R}=$ $0.812, \mathrm{P}<0.05)$. Higher $\mathrm{DO}$ and lower $\mathrm{NH}_{3}$ levels generally indicate low organic carbon and low nutrient contamination in the local marine environment. DO serves as an oxidizing agent that is sensitive to the amount of organic contamination in seawater, hence higher levels of DO are indicative of healthy and/or recovering environments. Even though both sponges and soft corals are known to be resistant towards environmental stressors in comparison to hard corals, without adverse effects (Koop et al. 2001; Fleury et al. 2004), it was found that their diversity tended to decrease with increasing anthropogenic pressures. Both sponges and soft corals are likely to favour oligotrophic conditions, as is the case for hard corals.
A similar result was reported by Powell et al. (2010) and showed the density of sponges was directly correlated to live coral cover.

\subsection{Bioactivity Potential of Sponges and Soft Corals}

A Spearman correlation analysis revealed a strong and significant relationship $(R>0.8, P<0.05)$ between the activities obtained with each of the three cancer cell lines (H460, MCF-7, and SF265) for each extract (Figure 5). Based on this samples if were categorized as High, Mod, Low or Inactive. The cytotoxicity exhibited by both sponges and soft corals, which are sessile, relates to their ability to defend themselves in a very competitive coral reef environment (Lages et al. 2006).

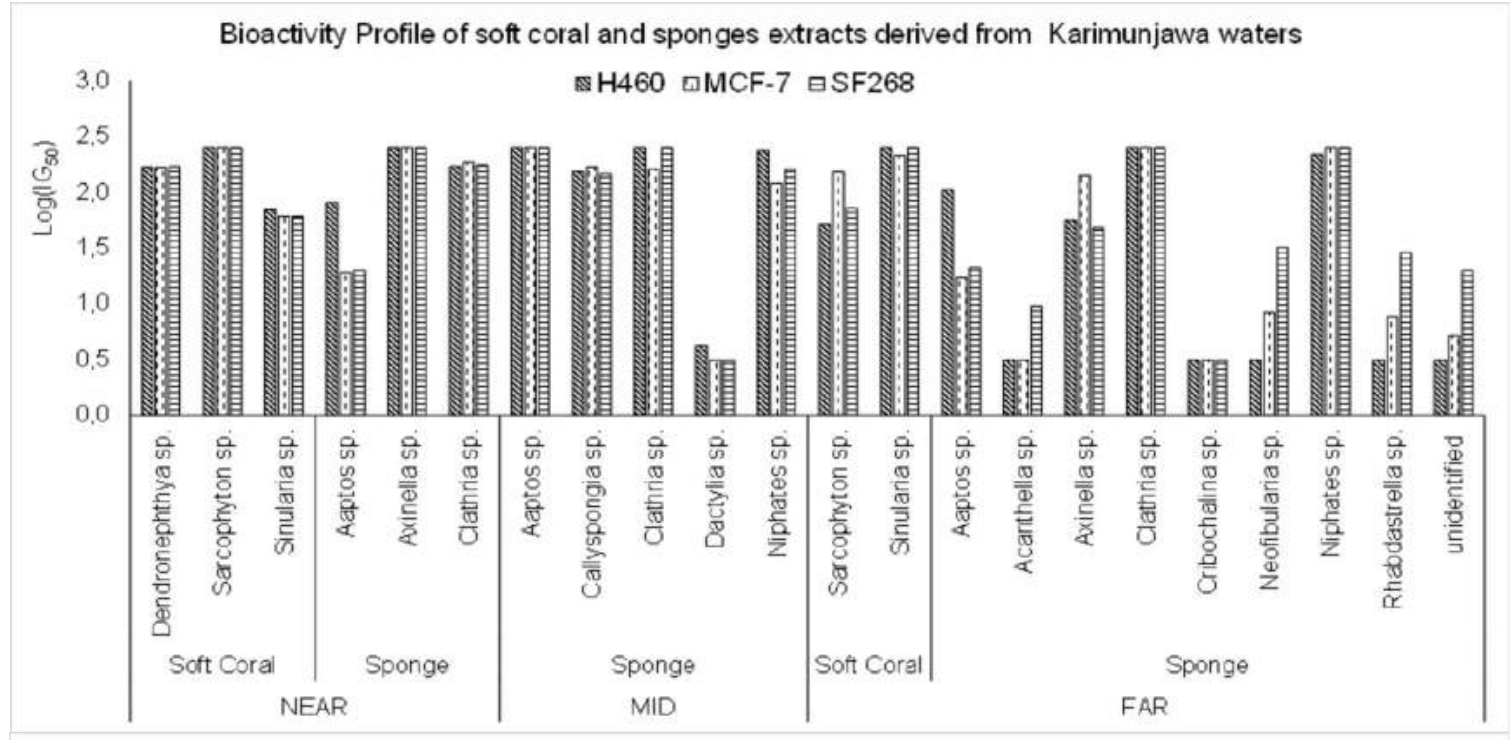

Bioactivity Profile of soft corals and sponges extracts derived from Seribu Islands waters

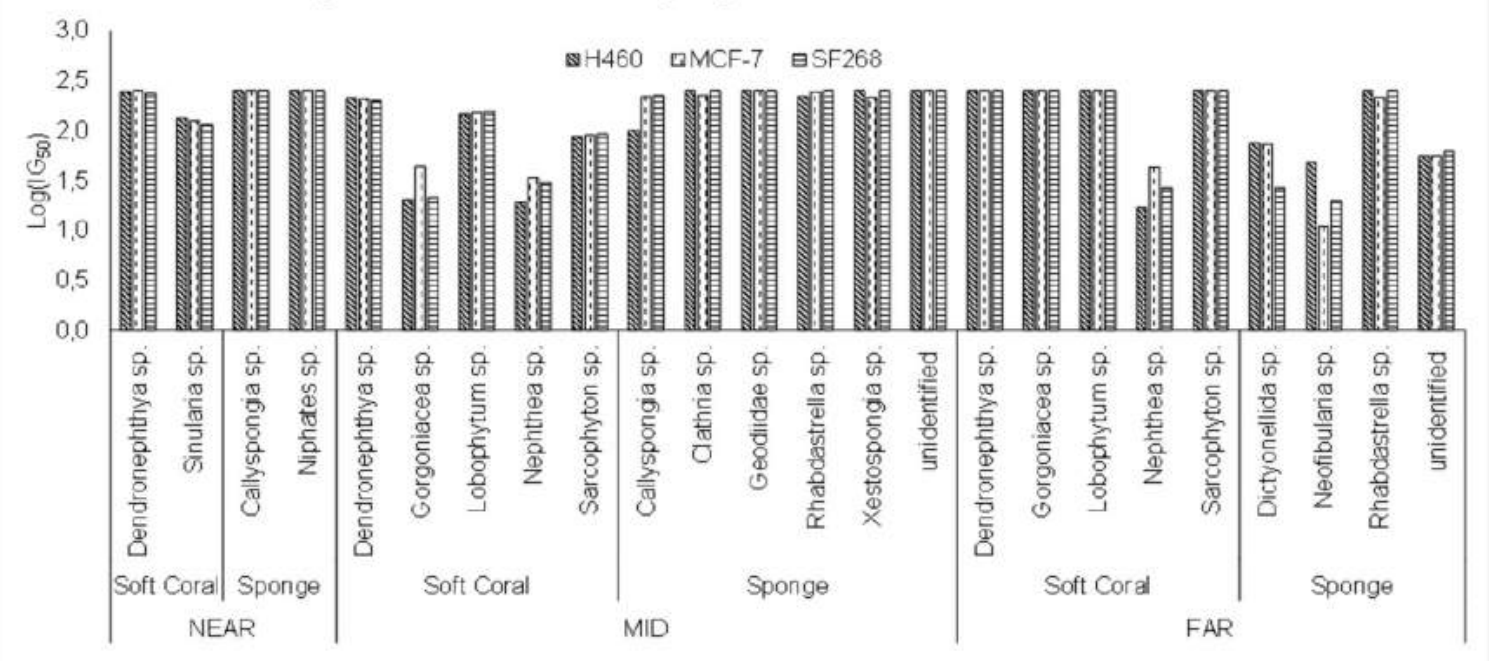

Figure 5. $\log \mathrm{IG}_{50}$ of methanolic extracts from sponges and soft corals from (a) Karimunjawa and (b) Seribu Islands Marine National Parks, with Near, Mid, and Far representing the distance of the site to the main inhabited island in the marine parks (Karimunjawa and Pramuka Islands; Figure 1). 


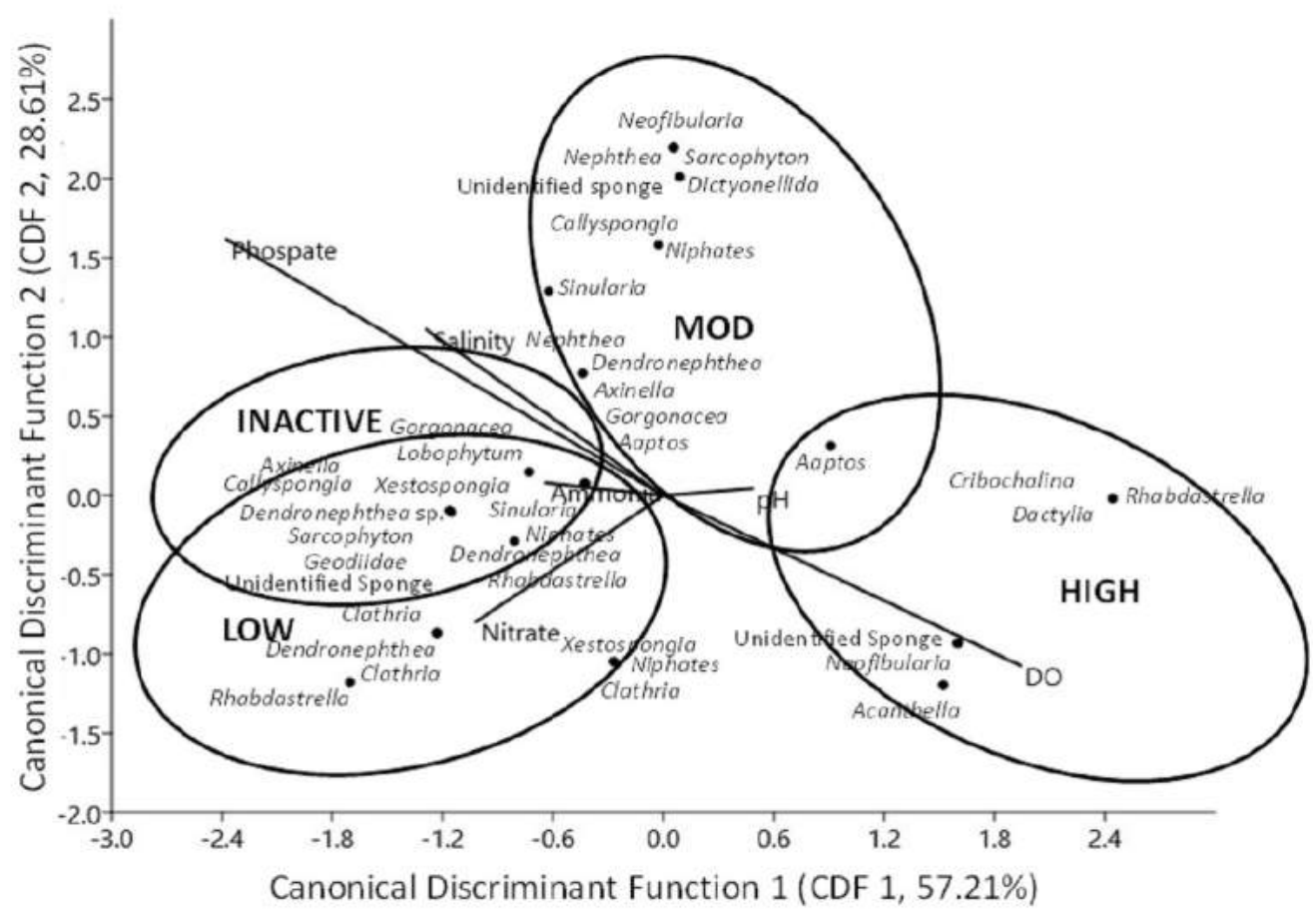

Figure 6. CDA (with 95\% eclipses) of environmental parameters in bioactivity groups of $\mathrm{High}\left(\mathrm{IG}_{50}<20 \mu \mathrm{g} / \mathrm{ml}\right.$ ), $\operatorname{Mod}\left(\mathrm{IG}_{50} 20-100 \mu \mathrm{g} / \mathrm{ml}\right)$, Low $\left(\mathrm{IG}_{50} 100-250 \mu \mathrm{g} / \mathrm{ml}\right)$, and Inactive $\left(\mathrm{IG}_{50}>250 \mu \mathrm{g} / \mathrm{ml}\right)$

High and moderate cytotoxic activities were observed for soft corals in the genera Sinularia, Nephthea, Sarcophyton, and the family Gorgoniacea. Indeed, soft corals are well known for their ability to produce cytotoxic cembranoid compounds (MichalekWagner et al. 2001; Lages et al. 2006; Januar et al. 2010; Rocha et al. 2011). Meanwhile, similar activities were exhibited by the $\mathrm{CH}_{3} \mathrm{OH}$ extracts of the sponges from the genera Aaptos, Dactylia, Dictyonellida, Acanthella, Axinella, Cribrochalina, Neofibularia, and Rhabdastrella. Various compounds have been detected in Indonesian sponges, particularly those from Karimunjawa and Seribu Islands Marine National Parks, such as the cytotoxic aaptamine from Aaptos $\mathrm{sp}$., and betaines, and/or various brominated compounds from Axinella sp.(Januar et al. 2007; 2009; Dewi et al. 2012), the source of which may in fact be their symbiotic bacteria (Uria \& Piel, 2009).

Statistical Kruskall-Wallis showed no significant difference between the cytotoxicity ( $\mathrm{IG}_{50}$ values) of samples from the two geographically separated locations (Seribu Islands and Karimunjawa Marine Parks) and their taxonomic grouping (sponges and soft corals). This finding indicates location does not directly influence the production of bioactive compounds by either sponges or soft corals. However, samples furthest from the inhabited islands (Far sites) had lower $I G_{50}$ values (higher activity) compared to those closest (Near sites).
Multivariate CDA of bioactivity groups (High, Mod, Low, and Inactive) and environmental parameters showed that specific combinations of these were related to higher cytotoxicity in sponges and soft corals (Figure 6). Specifically, the analysis showed higher $\mathrm{DO}$ and $\mathrm{pH}$, together with low nutrient levels $\left(\mathrm{PO}_{4}^{3-}, \mathrm{NO}^{3-}\right.$ and $\mathrm{NH}_{3}$ ) were related to a canonical function $(57.21 \%)$ that defined the High and Mod activity groups. In contrast, the Low and Inactive groups were related to higher nutrient values and lower $\mathrm{DO}$ and $\mathrm{pH}$. One-Way ANOSIM revealed no significant differences between the Inactive and Low groups or between the Mod and High groups as a result of the environmental parameters. However, a significant difference $(P<0.05)$ was observed between the Inactive/ Low groups and the Mod/High groups. Therefore, it can be generalized that there were two distinct environments: (1) high $\mathrm{DO}$, high $\mathrm{pH}$, and low nutrient promoting high bioactivity potential $\left(\mathrm{IG}_{50}<100 \mu \mathrm{g} / \mathrm{ml}\right)$ and (2) low DO and high nutrient levels reducing bioactivity potential $\left(\mathrm{IG}_{50}>100 \mu \mathrm{g} / \mathrm{ml}\right)$. This categorisation was supported by SIMPER analysis which that found $\mathrm{DO}, \mathrm{pH}, \mathrm{NH}_{3}$ and $\mathrm{PO}_{4}{ }^{3-}$ levels together explained the variance $(80.22 \%)$ of environmental parameters on bioactivity groups.

This study showed that the overall trends for bioactivity potential of sponges and soft corals at particular reefs were clearly influenced by human activities - stressors. These results support the 
findings of several previous ecological studies undertaken on single species. In particular, investigation of the soft coral, Nephthea spp., indicated that bioactive compound diversity was directly related to environmental parameters (Januar et al. 2011; 2012). Likewise, an earlier study focussing on Sarcopyton spp., showed that the production of cembranoids and the overall bioactivity decreased at higher nutrient levels, hence the soft coral was compromised, limiting its ability to compete for space and defend itself against predators (Fleury et al., 2004; Iswani et al., 2014). As shown by Turon and colleagues for sponges, there seems to be a clear trade-off between energy invested for growth and that used for the production of bioactive compounds (Turon et al. 2009).

\section{Conclusion}

The diversity of tropical soft corals and sponges was found to decrease closer to inhabited islands in both the Seribu Islands and Karimunjawa Marine National Parks. The observed decrease related directly to higher nutrient concentrations in these areas, which serve as indicators of increased anthropogenic pressures. Consequently, the bioactivity potential of the organisms being compromised was also negatively impacted as natural diversity decreased. Strategies for marine protection, for instance by mitigating the impacts of anthropogenic pressures, urgently need to be optimized to ensure biodiversity, and hence the bioactivity potential of its marine benthic organisms, is conserved.

\section{Acknowledgement}

This study was supported by AusAID Public Sector Linkage Program PSLP-Indonesia project ROU 37118. Our thanks go to Karimunjawa and Seribu Islands Marine National Parks officers, who organized sampling activities. We also thank Sri Iswani, Thamrin Wikanta, Muhammad Nursid, Nurrahmi Dewi Fajarningsih, Ifah Munifah, Ruri Wihardini, Helena Manik, and Nanik Dolaria, for their assistance with sample preparation and environmental parameter analyses.

\section{References}

Aeby, G.S., Williams, G. J., Franklin, E.C., Haapkyla, J., Harvell, C.D., Neale, S., Page, C.A., Raymundo, L., Vargas-Ángel, B., Willis, B.L., Work, T.M., \& Davy, S.K. (2011). Growth anomalies on the coral genera Acropora and Porites are strongly associated with host density and human population size across the Indo-Pacific. PloS one, 6(2), e16887.
Caras T., \& Pasternak, Z. (2009). Long-term environmental impact of coral mining at the Wakatobi marine park, Indonesia" Ocean \& Coastal Management, 52(10), 539-544.

Crabbe, M.J.C., Karaviotis, S., \& Smith, D.J. (2004). Preliminary comparison of three coral reef sites in the Wakatobi Marine National Park (S.E. Sulawesi, Indonesia): estimated recruitment dates compared with Discovery Bay, Jamaica. Bulletin of Marine Science, 74(2), 469-476.

De Caralt, S., Bry, D., Bontemps, N., Turon, X., Uriz, M.J., \& Banaigs, B. (2013). Sources of secondary metabolite variation in Dysidea avara (porifera: demospongiae): The importance of having good neighbors. Marine Drugs, 11(2), 489-503.

Dewi, A.S., Hadi, T.A., Januar, H.I., Pratitis, A., \& Chasanah, E. (2012). Study on the effects of pollutants on the production of aaptamines and the cytotoxicity of crude extract from Aaptos suberitoides. SQUALEN, Bulletin of Marine and Fisheries Postharvest and Biotechnology 7(3), 97-104.

Edinger, E.N., Jompa, J., Limmon, G.V., Widjatmoko, W., and Risk, M.J. (1998). Reef degradation and coral biodiversity in Indonesia: Effects of land-based pollution, destructive fishing practices, and changes over time. Marine Pollution Bulletin, 36(8), 617-630.

Fabricius, K. (2008). A brief photo guide to the shallowwater octocorals of the Rowley Shoals, Western Australia. Australian Institute of Marine Science. 39pp.

Fleury, B.G., Coll, J.C., Sammarco, P.W., Tentori, E., \& Duquesne, S. (2004). Complementary (secondary) metabolites in an octocoral competing with a scleractinian coral: effects of varying nutrient regimes. Journal Experimental Marine Biology and Ecology. 303(1), 115-131.

Haber, M., Carbone, M., Mollo, E., Gavagnin, M., \& llan, M. (2011). Chemical defense against predators and bacterial fouling in the Mediterranean sponges Axinella polypoides and A. verrucosa," Marine Ecology Progress Series, 422, 113-122.

Haapkyla, J., Unsworth, R. K. F., Seymour, A. S., Melbourne-Thomas, J., Flavell, M., Willis, B. L., \& Smith, D. J. (2009). Spatio-temporal coral disease dynamics in the Wakatobi Marine National Park, South-East Sulawesi, Indonesia, Diseases of Aquatic Organisms, 87, 105-115.

Hammer, O., Harper, D.A.T., \& Ryan, P.D. (2001). Past: Paleontological statistics software package for education and data analysis. Paleontological Electronics, 4(1), 1-9.

He, Q., Sun, R., Liu, H., Geng, Z., Chen, D., Li, Y., Han, J., Lin, W., Du, S., \& Deng, Z. (2014). NMR-based metabolomic analysis of spatial variation in soft corals. Marine Drugs. 12, 1876-1890.

Hooper, J.N.A., (2003). Sponguide: Guide for sponge collection and identification. Queensland Museum, Australia, 24pp.

Hoover, C.A., Slattery, M., Targett, N.M., \& Marsh, A.G. (2008). Transcriptome and metabolite responses to 
predation in a South Pacific soft coral. Biology Bulletin, 214, 319-328.

Huang, Y.C.A., Hsieh, H.J., Huang, S.C., Meng, P.J., Chen, Y.S., Keshavmurthy, S., Nozawa, Y., Chen, C.A. (2011). Nutrient enrichment caused by marine cage culture and its influence on subtropical coral communities in turbid waters. Marine Ecology Progress Series. 423, 83-93.

Iswani, S., Tohir, D., \& Januar, H.I. (2014). Identification of cytotoxic compounds in soft coral Sarcophyton sp. from Panggang Island water, Seribu Islands National Parks. Indonesian Journal of Pharmaceutical Sciences. 12(2), 1-5.

Januar, H.I., Hendrarto, B., Chasanah, E., \& Wright, A.D. (2011). Nephthea spp.: correlation between natural products production and pressure from local environmental stressors. Journal of Marine Science Research and Development. 8(002), 1-8.

Januar, H.I., Marraskuranto, E., Patantis, G., \& Chasanah, E. (2012). LC-MS Metabolomic Analysis of environmental stressors impacts to the metabolites diversity in Nephthea sp. Chronicles of Young Scientists. 2(4), 57-62.

Januar, H.I., Chasanah, E., Motti, C., Tapiolas, D., Liptrot, C., \& Wright, A.D. (2010). Cytotoxic cembranes from Indonesian specimens of the soft coral Nephthea sp. Marine Drugs. 8, 2142-2152.

Januar, H.I., Motti, C.A., Tapiolas, D.M., \& Wright, A.D. (2009). Dereplication analysis for identification of antibacterial compounds in Axinella sponges from Karimunjawa Islands waters. Indonesian Journal of Marine and Fisheries Post-harvest and Biotechnology 4, 79-86.

Januar, H.I., Patmaesari, L., Wikanta, T., \& Chasanah, E. (2007). Dereplication analysis of bioactive substances in polar fraction of Petrosia sp. from Seribu Islands waters. Indonesian Journal of Marine and Fisheries Post-harvest and Biotechnology 2. 129-136.

Koop, K., Booth, D., Broadbent, A., Brodie, J., Bucher, D., Capone, D., Coll, J.C., Dennison, W., Erdman, M., Harrison, P., Hoegh-Guldberg, O., Hutching, P., Jones, G.B., Larkum, A.W.D., O'Neil, J., Steven, A., Tentori, E., Ward, S., Williamson, J., \& Yellowless, D.
(2001). ENCORE: The effect of nutrient enrichment on coral reefs. Synthesis of results and conclusions. Marine Pollution Bulletin. 42(2), 91-120.

Lages, B.G., Fleury, B.G., Ferreira, C.E., \& Pereira, R.C. (2006). Chemical defense of an exotic coral as invasion strategy. Journal of Experimental Marine Biology and Ecology. 328(1), 127-135.

Michalek-Wagner, K., Bourne, D.J., \& Bowden, B.F. (2001). The effects of different strains of zooxanthellae on the secondary-metabolite chemistry and development of the soft-coral host Lobophytum compactum. Marine Biology. 138(4), 753-760.

Pawlik, J.R. (2011). The chemical ecology of sponges on Caribbean reefs: natural products shape natural systems. Bioscience. 61(11), 888-898.

Powell, A.L., Hepburn, L.J., Smith, D.J., \& Bell, J.J. (2010). Patterns of sponge abundance across a gradient of habitat quality in the Wakatobi Marine National Park, Indonesia. The Open Marine Biology Journal, 4(31), 31-38.

Rocha, J., Peixe, L., Gomes, N., \& Calado, R. (2011). Cnidarians as a source of new marine bioactive compounds - An overview of the last decade and future steps for bioprospecting. Marine Drugs. 9(10), 1860-1886.

Sachoemar, S.I. (2008). Environmental characteristics of Seribu Islands. Indonesian Journal of Water Sciences. 4(2), 109-114.

Shuiwang, D., Zhang, S., \& Huang, H. (2000). Transport of dissolved inorganic nitrogen from the major rivers to estuaries in China. Nutrient Cycling in Agroecosystems. 57(1), 13-22.

Skehan, P., Storeng, R., Scudiero, D., Monks, A., McMahon, J., Vistica, D., Warren, J.T., Bokesch, H., Kenny, S., \& Boyd, M. R. (1990). New colorimetric cytotoxicity assay for anticancer-drug screening. Journal of the National Cancer Institute, 82(13), 1107-1112.

Turon, X., Martí, R., \& Uriz, M. J. (2009). Chemical bioactivity of sponges along an environmental gradient in a Mediterranean cave. Scientia Marina. 73(2), 387-397.

Uria, A., \& Piel, J. (2009). Cultivation-independent approaches to investigate the chemistry of marine symbiotic bacteria. Phytochemistry Reviews, 8, 401414 